\title{
Pendampingan Penyusunan Laporan Keuangan dengan Teknik Pembukuan Sederhana pada Pelaku UMKM Scale-Up di Wilayah Tangerang Selatan
}

\author{
Dila Angraini, ${ }^{1}$, Tri Utami ${ }^{2}$, Dea Annisa ${ }^{3}$, Zulfa Rosharlianti, ${ }^{4}$, Wiwit Irawati, ${ }^{5}$ \\ S1 Akuntansi, Fakultas Ekonomi, Universitas Pamulang \\ Idosen00879@unpam.ac.id ;2dosen00882@unpam.ac.id ; ${ }^{3}$ dosen00883@unpam.ac.id; \\ ${ }^{4}$ dosen00876@unpam.ac.id ; ${ }^{5}$ wiwitira@unpam.ac.id \\ *dosen00879@unpam.ac.id
}

\begin{abstract}
Abstrak
Pengabdian kepada masyarakat (PKM) ini bekerjasama dengan Rumah Pemberdayaan Masyarakat (RPM) Institute Tangerang Selatan. Tujuan dari PKM ini adalah untuk memberikan pendampingan penyusunan pembukuan laporan keuangan UMKM dengan teknik sederhana dengan menggunakan program Ms. Excel. Pelaku UKM yang terlibat serta dalam PKM ini berjumlah 50 orang dengan waktu pelatihan dan pendampingan pada tanggal 26 November 2020 secara virtual online melalui Zoom Meeting. Metode yang digunakan dalam PKM ini adalah penyuluhan atau ceramah, tutorial, diskusi, pendampingan dan assesment. Hasil PKM yaitu membantu pelaku UMKM dalam memahami masalah pembukuan dan penusunan serta perhitungan Harga Pokok Penjualan serta mencatat dan menghitung persediaan dengan lebih akurat dibantu dengan program Ms. Excel. Pelaku UMKM dengan tepat dan disiplin dalam melakukan pembukuan menggunakan program Ms. Excel. Diharapkan PKM ini dapat bermanfaat untuk berbagai pihak diantaranya pelaku UMKM itu sendiri, Ikatan Akuntan Indonesia, pemerintah dan bagi akademisi.
\end{abstract}

Kata Kunci: Laporan Keuangan, Ms. Excel, UMKM, RPM Institute

\begin{abstract}
Community service (PKM) with the Community Empowerment House (RPM) Institute South Tangerang. The purpose of this PKM is to assist in the preparation of MSME financial report bookkeeping with simple techniques using the Ms. program. Excel. The UKM players involved in this PKM maybe 50 people with online training and mentoring on November 26, 2020 through the Zoom Meeting. The methods used in this PKM are counseling or lectures, tutorials, discussions, mentoring, and assessment. The results of the PKM is helping MSME players in understanding the problems of bookkeeping and composing as well as calculating the Cost of Goods Sold and recording and calculating inventory more accurately, assisted by Ms. Excel. UMKM players are precise and disciplined in doing bookkeeping using the Ms. program. Excel. It is hoped that this PKM can be useful for various parties including MSME actors themselves, the Indonesian Accountants Association, the Government, and academics..
\end{abstract}

Keywords: Financial Statements, Ms. Excel, UMKM, RPM Institute 


\section{PENDAHULUAN}

Usaha Mikro Kecil dan Menengah (UMKM) memiliki potensi tumbuh kembang yang besar dalam meningkatkan taraf hidup rakyat banyak. Hal ini ditunjukkan oleh keberadaan UMKM yang telah mencerminkan wujud nyata kehidupan sosial dan ekonomi bagian terbesar dari rakyat Indonesia. Sebagai salah satu komponen dalam industri nasional, Usaha Mikro, Kecil, dan Menengah (UMKM) berperan penting dalam perekonomian nasional, penyerapan tenaga kerja, pemerataan distribusi hasil-hasil pembangunan, dan penanggulangan kemiskinan. Data statistik menunjukan bahwa jumlah unit usaha kecil mikro dan menengah (UMKM) mendekati angka 99,98\% dari total unit usaha di Indonesia dengan kontribusi sebesar 56\% dari total PDB di Indonesia. Hal ini mencerminkan tingginya signifikansi peran UKM bagi pemerataan ekonomi Indonesia

Pada dasarnya produk yang dihasilkan dan ditawarkan para pelaku UMKM tidak dapat dianggap remeh, memiliki ciri khas yang berbeda antar satu jenis produk yang sama pun sangat sering terjadi. Untuk itu kelihaian dalam memasarkan produk harus ditingkatkan, akibat tingginya persaingan. Tidak hanya soal pemasaran kesiapan pengelolaan 'rumah tangga' industri juga harus dipersiapkan sebaik mungkin, diantaranya kesiapan pengelolaan bisnis, pengelolaan keuangan usaha, pengelolaan stok barang sampai pada pengelolaan pelayanan konsumen. Untuk mempersiapkan 'rumah tangga' industri demi tetap bertahannya suatu usaha, para pelaku UKM perlu dibantu serta didampingi.

Di Kota Tangerang Selatan khususnya, para pelaku UMKM banyak dibantu oleh Rumah Pemberdayaan Masyarakat (RPM). Rumah Pemberdayaan Masyarakat adalah sebuah lembaga nirlaba yang berfokus pada pelatihan dan pendampingan dalam berbagai programprogram pemberdayaannya. Beberapa bentuk materi pelatihan yang diberikan adalah mengenai pemahaman tentang strategi pemasaran dan bisnis, Penyusunan laporan keuangan, Strategi Distribusi, Market Place dan lain-lain.

Dosen Program Studi Sarjana Akuntansi bekerjasama dengan Rumah Pemberdayaan Masyarakat melalui Klinik Bisnis UMKM (Scale-Up) yang meliputi tahapan pendidikan atau pelatihan, pengembangan produk, pemasaran dan permodalan serta pembinaan berkala Scale-up Bisnis. Program ini bertujuan untuk mencetak pelaku usaha yang siap berkembang menuju kelas yang lebih tinggi, mempunyai kapabilitas dalam wirausaha berbasis digital dan berdaya saing di era digital 4.0. Penerima Manfaat program ini diantaranya: a) Memiliki Usaha (minimal sudah berjalan 1,5 tahun), b) Produk kuliner, c) Mengikuti seleksi 
interview dan kurasi Produk, d) Mengikuti seluruh rangkaian pelatihan dan pembinaan.

Peran usaha mikro kecil dan menengah juga sangat penting dalam menopang perekonomian Kota Tangerang Selatan. Berdasarkan data yang diperoleh dari Dinas Koperasi dan UKM, sebagian besar UMKM di Kota Tangerang Selatan bergerak di usaha kuliner yaitu 5.462 usaha, kemudian disusul dengan usaha sembako/toko sebanyak 5.051 usaha dan jasa sebanyak 2.232 usaha. Jenis UMKM yang masih sedikit dikembangkan di Kota Tangerang Selatan adalah usaha di bidang perikanan yaitu hanya 1.089 usaha (Dinas Komunikasi dan Informatika \& BPS TangSel, 2019).

Tabel 1.1. Jumlah UMKM di Wilayah Tangerang Selatan

\begin{tabular}{lrrrr}
\hline \multicolumn{1}{c}{ Jenis UKM } & UMKM Mikro & UMKM Kecil & $\begin{array}{c}\text { UMKM } \\
\text { Menengah }\end{array}$ & $\begin{array}{c}\text { Total } \\
\text { UMKM }\end{array}$ \\
\hline Kuliner & 1.451 & 2.392 & 1.619 & $\mathbf{5 . 4 6 2}$ \\
Fashion & 980 & 152 & 124 & $\mathbf{1 . 2 5 6}$ \\
Sembako/Toko & 1.556 & 2.149 & 1.346 & $\mathbf{5 . 0 5 1}$ \\
Aksesoris & 970 & 155 & 86 & $\mathbf{1 . 2 1 1}$ \\
Perikanan & 938 & 54 & 97 & $\mathbf{1 . 0 8 9}$ \\
Pertanian & 952 & 90 & 97 & $\mathbf{1 . 1 3 9}$ \\
Konveksi & 971 & 95 & 87 & $\mathbf{1 . 1 5 3}$ \\
Restoran & 977 & 208 & 136 & $\mathbf{1 . 3 2 1}$ \\
Konter/Hp & 1.028 & 356 & 183 & $\mathbf{1 . 5 6 7}$ \\
Jasa & 1.115 & 679 & 438 & $\mathbf{2 . 2 3 2}$ \\
Furtinuture & 951 & 92 & 154 & $\mathbf{1 . 1 9 7}$ \\
Kreatif & 953 & 99 & 51 & $\mathbf{1 . 1 0 3}$ \\
\hline Total & $\mathbf{1 2 . 8 4 2}$ & $\mathbf{6 . 5 2 1}$ & $\mathbf{4 . 4 1 8}$ & $\mathbf{2 3 . 7 8 1}$ \\
\hline Sumber: Dinas Koperasi dan UKM Kota Tangerang Selatan & & & \\
\hline
\end{tabular}

Kota Tangerang Selatan didapuk sebagai

kota terbaik untuk iklim ekonomi Usaha Mikro Kecil Menengah (UMKM) melalui Penghargaan Natamukti Nindya. Penghargaan ini diberikan Menteri
Koperasi dan Usaha Kecil dan Menengah Indonesia Anak Agung Gede Ngurah Puspayoga dan President ICSB Hermawan Kartawijaya, Selasa 28 November 2017 dalam acara Indonesia Council of Small Business (ICSB) 'Indonesia City Award' di Kementerian Koperasi dan Usaha Kecil Menengah (UKM), Jakarta (Tempo.Co, diakses pada 6 November 2020)

Dalam perkembangannya terdapat beberapa kendala yang terjadi dilapangan yaitu: Sejumlah pengusaha skala kecil dan menengah di Tangerang Selatan terkendala oleh terbatasnya tenaga produksi dan pemasaran sehingga bisnisnya tidak bisa berkembang lebih cepat, serta berkaitan dengan pembukuan yang dilakukan oleh para pelaku UMKM yang masih sangat sederhana dan minim pengentahuan mengenai pencatatan keuangn yang baik dan benar serta sesuai dengan standar akuntansi keuangan yang berlaku di Indonesia. Melihat keadaan yang terjadi maka dirasa perlu adanya pendampingan bagi sektor UMKM tersebut sehingga mampu bersaing skala nasional. Tidak dapat dipungkirin bahwa perkembangan bisnis Indonesia masih sangat minim, hal ini terbukti dari beberapa kendala yang dihadapi dilapangan. Akses mengenai informasi terkait pengembangan bisnispun 
masih sangat terbatas, terlebih background pendidikan pelaku UMKM yang rendah.

Dari banyaknya jenis usaha perdagangan di kota Tangerang Selatan, Rumah Pemberdayaan masyarakat menggolongkan UMKM berdasarkan lamanya usaha perdagangan dan minimal omset. Untuk jenis usaha perdagangan dengan kategori minimal usaha 2 tahun dan dengan omset minimal lima juta sebulan, digolongkan sebagai kategori UMKM ScaleUp. para pelaku UMKM ScaleUp harus benar-benar bersaing tidak hanya dari segi pemasaran, tetapi juga kesiapan pengelolaan keuangannya, tujuannya agar para pelaku UMKM Tangerang Selatan dapat melakukan perkembangan usaha dengan tepat dan sesuai sasaran. Lemahnya kesadaran akan pentingnya disiplin pembukuan atau pengelolaan keuangan masih menjadi hal yang serius di lingkungan para pelaku UMKM Tangerang Selatan. Padatnya aktivitas produksi dan pemasaran serta kurangnya informasi mengenai tata kelola menjadikan pelaku UMKM mengabaikan pencatatan atas transaksi ekonominya. Perlu adanya penyuluhan dan pendampingan mengenai penyusunan laporan keuangan bagi UMKM serta cara termudahnya dalam membantu pengelolaan keuangan baik secara manual maupun digital.

\section{METODE}

Setelah dipahami, bahwa pencatatan akuntansi keuangan usaha masih menjadi kendala yang dihadapi bagi para pelaku UMKM, maka pemecahan permasalahan ketidakdisiplinan pembukuan sederhana akibat kurangnya informasi mengenai standar akuntamsi keuangan yang berlaku bagi UMKM, dilakukan dengan beberapa pendekatan yang dilakukan secara bersama sama yaitu:

1. Berbasis Kelompok Bapak/Ibu pelaku UMKM, seluruh kegiatan pengabdian masyarakat dilakukan kepada masyarakat dilakukan dengan menggunakan kelompok sebagai media belajar dan pendampingan, perencanaan dan memonitor dan evaluasi seluruh kegiatan pengabdian masyarakat. Pada kesempatan ini para pelaku UMKM diberikan penyuluhan mengenai pentingnya melakukan pencatatan transaksi keuangan. Selain itu, materi yang diajarkan mengenai standar akuntansi keuangan entitas mikro kecil menengah yang disampaikan dengan bahasa sehari-hari para pelaku UMKM. Berbasis kelompok maksudnya adalah para pelaku UMKM yang terbagi dalam beberapa kelompok jenis usaha, dikelompokan berdasasrkan bidang usaha dan jenis usahanya. Pada kesempatan kali ini peserta 
UMKM ScaleUp adalah UMKM bidang perdagangan kuliner. Tujuan dibuat perkelompok adalah agar model pembelajaran akuntansi dapat dengan mudah dipahami, dan dapat dipraktekan langsung pada usaha masing-masing peserta ScaleUp, daripada yang berbeda bidang maupun jenis usahanya.

2. Komprehensif, seluruh kegiatan pengabdian masyarakat dilakukan secara serentak terkait standar UMKM yang berlaku dan aplikasinya yang dilakukan melalui pelatihan dan pendampingan tenaga praktisi keuangan khusus UMKM. Materi yang disampaikan adalah penerapan „manajemen laci dompet traficlight", di mana materi tersebut merupakan cara mudah mempraktikan pengelolaan SAK EMKM dengan cara manual. Permasalahan manajemen keuangan laci UMKM merupakan masalah yang bisa ditemui di hampir seluruh pelaku UMKM. Metode pendampingan yang dilakukan adalah tatap muka satu kali sekaligus pengarahan, selanjutnya para peserta ScaleUp akan dibimbing selama tiga bulan dalam masa hari kerja (seninjumat) ataupun hari libur (sabtu dan minggu) melalui gawai.
3. Berbasis teknologi digital dengan pengembangan diri untuk beralih ke „digital recording ${ }^{\text {ee }}$ sehingga mengefisiensikan waktu di antara aktivitas rantai produksi yang padat, serta menjadikan pencatatan lebih tepat dan akurat untuk pelaku UMKM ScaleUp Tangerang Selatan. Sosialisasi mengenai penerapan teori pencatatan keuangan yang baik yang berdasarkan pada standar keuangan, perlu dilakukan. Alat yang digunakan oleh para pelaku UMKM untuk mencatat transaksi dan melakukan penginputan data keuangan adalah dengan menggunakan program Excel yang lebih sederhana karena saat ini penggunaan laptop, PC maupun Handphone berbasis Android dapat menginstal aplikasi Ms Office di mana hal ini merupakan suatu yang lumrah mengingat dengan semakin berkembangannya digitalisasi di era modern seperti sekarang ini.

Selanjutnya ketiga metode di atas diimplementasikan dalam 4 (empat) tahapan yaitu (1) sosialisasi, (2) peningkatan kompetensi, (3) pendampingan (4) monitoring dan evaluasi. Diharapkan sosialisasi Standar akuntansi keuangan entitas mikro kecíl menengah dapat bekerja sama atau memdapat dukungan penuh dari pihak Bank Indonesia selaku creator dari SI APIK ini dan Ikatan Akuntan Indonesia (IAI) selaku sponsor dan 
pembuat Standar Akuntansi Keuangan Entitas Mikro Kecil Menengah.

Pelaksanaan kegiatan Pengabdian pada Masyarakat ini dilakukan dengan menggunakan metode ceramah, tutorial, diskusi, pendampingan dan konsultasi, dan assesment. Adapun sistematika pelaksanaan kegiatan pengabdian ini adalah sebagai berikut:

Langkah 1 (Metode Ceramah): Peserta diberikan motivasi agar memiliki kemauan untuk menggunakan akuntansi dalam kegiatan bisnisnya. Selain itu, peserta diberikan materi gambaran umum tentang akuntansi UMKM dan peran penting akuntansi bagi UMKM.

Langkah 2 (Metode Tutorial): Peserta pelatihan diberikan materi akuntansi mulai dari pencatatan sampai dengan menyusun laporan keuangan dengan program Ms Excel. Langkah kedua diselenggarakan selama 1 hari, masing-masing 1 jam per hari terbagi dalam dalam 2 sesi, sesi pertama pukul 08:00 - 12:00 dan sesi kedua pukul 13:00 - 17:00.

\section{Langkah 3 (Metode Diskusi): Peserta} pelatihan diberikan kesempatan untuk mendiskusikan permasalahan yang berkaitan dengan keuangan UMKM yang selama ini dihadapi. Langkah ketiga diselenggarakan selama 1 jam.

Langkah 4 (pendampingan dan konsultasi): peserta diberi kesempatan untuk didampingi selama \pm 1 bulan dalam menyusun laporan keuangan. Peserta diberi kesempatan untuk melakukan pertemuan secara virtual atau melalui chat di grup Whatshapp dengan para mentor di waktu dan tempat yang telah disepakati.

Langkah 5 (Evaluasi/ Assesment): tahap pertama evaluasi, peserta diuji dengan diberi batas waktu apakah mengumpulkan laporan keuangan perusahaannya yang telah diajarkan. Evaluasi tahap kedua, peserta diuji apakah laporan yang disajikan benar atau salah.

\section{HASIL DAN PEMBAHASAN}

Kegiatan pelatihan akuntansi UMKM bagi UMKM untuk meningkatkan bonafiditas dan kedisplinan pelaku UKM, dilaksanakan selama 5 tahap dalam beberapa hari. Adapun susunan acara pelatihan sebagai berikut:

\section{Tabel 2. Susunan Acara Pelatihan}

\begin{tabular}{|l|l|l|l|}
\hline No & Hari/Tanggal & Materi & Waktu \\
\hline 1 & Jumat, 30 & Q and A & $08.00-$ \\
& Oktober 2020 & general finance & 09.30 \\
\hline
\end{tabular}




\begin{tabular}{|c|c|c|c|}
\hline & & $\begin{array}{l}\text { Peserta } \\
\text { Pengantar / } \\
\text { Pendahuluan } \\
\text { Akuntansi } \\
\text { (SAK-EMKM) } \\
\text { Materi } \\
\text { Menghitung } \\
\text { HPP, } \\
\text { Persediaan dan } \\
\text { Membuat } \\
\text { Laporan } \\
\text { Keuangan } \\
\text { dengan MS. } \\
\text { Excel }\end{array}$ & $\begin{array}{l}09.30- \\
12.00 \\
13.00- \\
15.00\end{array}$ \\
\hline 2 & $\begin{array}{l}\text { Tidak } \\
\text { terjadwal }\end{array}$ & $\begin{array}{l}\text { Pendampingan/ } \\
\text { konsultasi } \\
\text { UMKM }\end{array}$ & $\begin{array}{l}30-60 \\
\text { menit/ } \\
\text { hari }\end{array}$ \\
\hline
\end{tabular}

Pelaksanaan penyuluhan dan pelatihan pada tanggal 30 Oktober 2020 dari pukul 08.00 sampai dengan 15.00. Acara pertama diawali dengan registrasi peserta sekaligus mengisi tanya jawab seputar keuangan umum usaha peserta. Selanjutnya, dilanjutkan dengan pemberian materi pertama oleh Ibu Dea Annisa S.E., M.Ak. dengan topik materi pengenalan SAKEMKM dan seputar akuntansi UMKM. Materi ini membahas pentingnya akuntansi bagi UMKM dan dilanjutkan dengan materi menghitung HPP dan Persediaan.

Materi kedua yaitu pelatihan akuntansi sederhana menggunakan Ms. Excel yang dipandu oleh Ibu Zulfa Rosharlianti, S.E.,
M.Ak. Materi yang dipilih adalah UKM dengan jenis usaha dagang, materi berlangsung selama 4 jam. Dari pukul 13.00 - 15.00. Acara dilakukan secara virtual dengan menggunakan zoom cloud meeting mengingat PKM ini diselenggarakan dalam kondisi pandemic Covid-19.

Untuk selanjutnya pendampingan disesuaikan dengan usaha peserta masingmasing dilakukan pada hari kerja dan hari libur pada jam dan tempat yang telah disepakati sampai tanggal 6 Desember 2020 secara virtual maupun dapat dilakukan secara online lewat chat di grup whatshapp. Pendampingan dilakukan untuk persiapan assessment. Assesment dilakukan pada tanggal 7 Desember 2020.

Pelaksanaan pelatihan pada hari Jumat 30 Oktober 2020 berjalan dengan cukup lancar. karena dilakukan secara online maka kendala yang dihadapi adalah masalah koneksi/ jaringan yang tidak stabil dari masing-masing peserta. Materi pertama yang diberikan adalah pengenalan atau pendahuluan mengenai akuntansi yang berdasarkan pada SAK-EMKM yang berlaku. pemateri memberikan penjelasan pentingnya akuntansi bagi UMKM. Sebagian besar audiens belum mengerti fungsi akuntansi, bahkan sebagian besar peserta pelatihan menganggap bahwa akuntansi 
adalah bidang yang rumit, susah, dengan usaha peserta masing-masing merepotkan, menghabiskan waktu. Materi dilakukan pada hari kerja dan hari libur pada pertama ini diisi dengan penguatan jam dan tempat yang telah disepakati. pentingnya akuntansi bagi usaha kecil Pendampingan dilakukan selama \pm 1 bulan (UMKM). Pada sesi ini terjadi diskusi yang menarik antara audiens dengan pemateri mengenai konsep dasar usaha. Beberapa audiens memiliki persepsi berebda tentang usaha atau entitas. Berdasarkan diskusi konsep entitas ini akhirnya diperoleh pemahaman konsep entitas. Setelah diperoleh kesepakatan tentang konsep entitas, dilanjutkan dengan fungsi pelaporan keuangan bagi entitas dan disambung dengan penjelasan mengenai cara menghitung Harga Pokok Penjualan dan Persediaan.

Setelah materi pertama dilanjutkan dengan materi kedua mengenai transaksitransaksi akuntansi UMKM yang diinput menggunakan Ms. Excel. Pada sesi ini, pemateri memberikan materi tentang cara mudah menggunakan MS. Excel. Kemudian bersama-sama peserta diminta menganalisa contoh transaksi dari pemateri kemudian menginputnya menggunakan MS. Excel Langkah-langkah dan maksud dari tiap transaksi dijelaskan oleh pemateri. Pengabdi yang lain menjadi instruksi pendamping ketika peserta menginput transaksi pada MS. Excel . Selanjutnya pendampingan untuk menggunakan MS. Excel yang disesuaikan sampai bulan Desember 2020, pendampingan dilakukan untuk persiapan assessment.

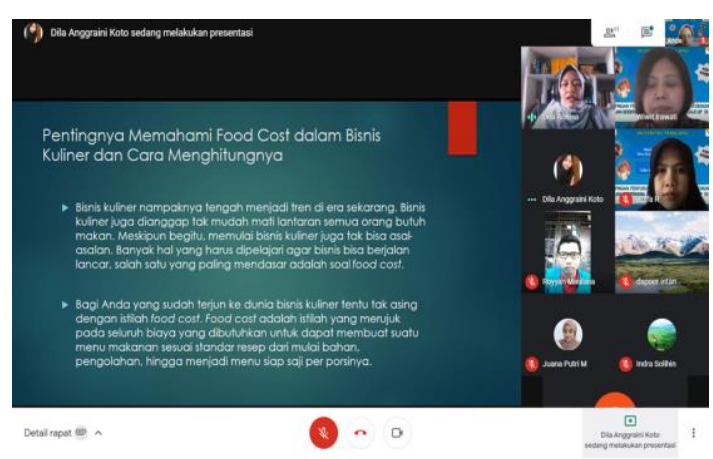

Gambar 1. Peserta PKM dan Narasumber Saat Sesi Materi

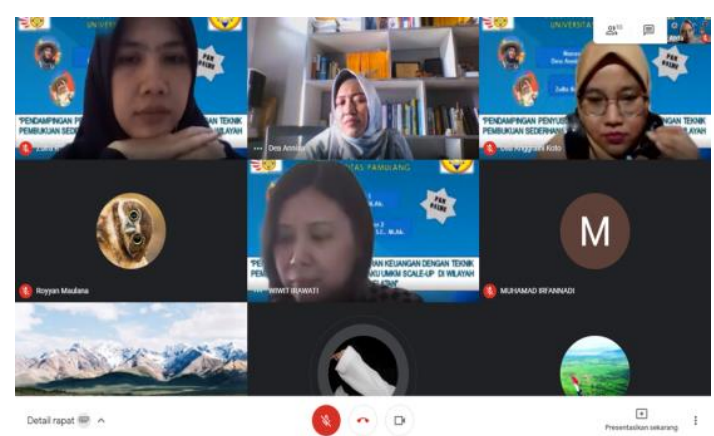

Gambar 2. Peserta PKM dan Narasumber Sebelum Sesi Materi

\section{KESIMPULAN}

Kegiatan pelatihan akuntansi UMKM bagi usaha mikro, kecil, menengah (UMKM) untuk meningktakan bonafiditas perusahaan berjalan dengan lancar. Sekaligus 
meningkatkan kedisplinan pelaku UMKM terhadap pencatatan akuntansi. Semua peserta antusias mengikuti acara hingga

\section{REFERENSI}

Exposure Draft Standar Akuntansi Keuangan Entitas Mikro Kecil Menengah (SAK-EMKM). 2016. IAI: Jakarta Selatan.

Pedoman Teknis Pencatatan Transaksi Keuangan Usaha Kecil Badan Usaha Bukan Badan Hukum Sektor Perdagangan. 2015. Bank Indonesia: Jakarta

RPIJM (Rencana Program Investasi Jangka Menengah) Bidang Cipta Karya Tahun 2019-2023. 2019. Tangerang Selatan. Bab 2.

Standar Akuntansi Keuangan Entitas Mikro Kecil Menengah (SAK-EMKM). 2018. IAI: Menteng. Jakarta Selatan.

Setyorini, dkk. (2012). Pelatihan Akuntansi UMKM Bagi UMKM Untuk Meningkatkan Kinerja Keuangan Perusahaan. UNY selesai dan merasakan manfaat pelatihan bagi kemajuan usaha mereka.

https://goukm.id/sak-emkm/ diakses pada tanggal 06 januari 2020. Pukul 00:54

Tejo Nurseto, - Strategi Menumbuhkan Wirausaha Kecil Menengah yang Tangguh\|, dalam Jurnal Ekonomi \& Pendidikan Vol.1 No.1 februari 2004, hlm. 3.

Mulyadi Nitisusastro, Kewirausahaan \& Manajemen Usaha Kecil, Alfabeta, Bandung, 2010, hlm. 26-27.

Febra Robiyanto, Akuntansi Praktis untuk Usaha Kecil dan Menengah, Studi Nusa, Semarang, 2004, hlm. 5. 5Undang-Undang Usaha Mokro, Kecil dan Menengah. Pustaka Mahardika, Yogyakarta, 2013, hlm. 3. 